\title{
Implementation of Curriculum 2013 in the Application of Integrated Thematic Learning in Primary School
}

\author{
Sri Sugiharti \\ Elementary School Teacher Education \\ Universitas Negeri Malang \\ Malang, Indonesia \\ srisugiharti848@yahoo.co.id
}

\begin{abstract}
Curriculum 2013 is a curriculum developed to enhance and balance the skills of soft skill and hard skill in the form of attitude, skills and knowledge. Curriculum 2013 emphasises the output of students who have characters such as religious, honest, tolerance, discipline, hard work, creative, independent, democratic, curiosity, spirit of nationality, love of the homeland, respect for achievement, friendship/ communicative, love peace, caring for the environment, social care, and responsibility. Implementation of learning includes: initial activities, core activities, i.e. observing, questioning, associating, experimenting, and networking and closing activities. Teachers are required to be more creative in developing the media. Assessment techniques and instruments in the Curriculum 2013 are grouped into 3 namely competency assessment of attitude, knowledge and skill.
\end{abstract}

Keywords - implementation of curriculum 2013, integrated thematic learning, elementary school

\section{CURRICULUM 2013}

Curriculum 2013 began to be implemented in the academic year $2013 / 2014$ or since July 15,2013 . The old curriculum was considered to emphasize more on the cognitive aspects that refer only to the knowledge of learners. Regarding curriculum changes, various parties consider the need to apply competency-based curriculum as well as characters that are expected to equip learners with various attitudes and abilities in accordance with the development of globalization as it is today.

Curriculum 2013 is a curriculum developed to improve and balance the soft skill and hard skills in the form of attitudes, skills and knowledge [1]. In this case, Curriculum 2013 seeks to better balance between attitudes and skills through knowledge in school. In other words, between soft skills and hard skills, it can be embedded in a balanced and applicable in everyday life.

\section{OBJECTIVES OF THE CURRICULUM YEAR 2013}

Curriculum 2013 emphasizes the output of students who have character. The characters in question are 18 characters: (1) Religious, (2) Honest, (3) Tolerance, (4) Discipline, (5) Hard work, (6) Creative, (7) Independent, (8) Democratic , (9) Curiosity, (10) Spirit of nationality, (11) Love of the homeland, (12) Respect for achievement, (13) Friendly / communicative, (14) Love of peace, (15) Fond of reading,
(16) Environment, (17) Social care, and (18) Responsibility. [2].

\section{INTEGRATED THEMATIC LEARNING}

The development of elementary school-age learning is strongly influenced by aspects of himself and his environment. In the process of development, students certainly adapt to the environment (cognitive developmental theory). According to Piaget [3], each child has a cognitive structure scheme, the concept system that exists in the mind as a result of understanding the objects that exist in the environment.

Learning on the curriculum 2013 is using integrated thematic learning. Regulation of the Minister of Education and Culture No. 67 of 2013 which states that curriculum 2013 for elementary schools is designed using integrated thematic learning. Integrated thematic learning is a learning that combines several subjects into a theme. Thematic learning is an integrated learning that uses the theme as a unifying material in several subjects simultaneously in one meeting [4].

In line with that, thematic learning is the first learning with reference to the characteristics of learners and implemented in an integrated manner between themes with one another and between subjects [1]. In Curriculum 2013, the learning used is integrated thematic learning. Integrated thematic learning is a learning that combines subjects into a theme. Kemendikbud [5] states "integrated thematic learning is a learning approach that integrates the various core competencies, basic competencies from various subjects into various themes and sub-themes.

Each learning has special characteristics, as well as thematic learning. In line with the above statement, Rusman [3] explains that the characteristics of thematic learning, including student-centred, direct experience, less obvious of subject classification, presenting concepts from various subjects, flexible, learning outcomes according to interests and needs of students, and using the principles of learning while playing and fun.

Student centred, it means that students are placed as study subjects, while the teacher plays more role as facilitator, which is to facilitate student to do learning 
activity. The immediate experience in question is that students are confronted with something concrete for the understanding of something that is abstract. The separation between subjects is not very clear, i.e. the focus of this study is directed to the discussion of the themes that are closest and related to student life. Presenting the Concept of various subjects i.e. presenting various concepts from various subjects. Students are expected to be able to understand the whole theme concepts, to assist students in solving the problems faced in everyday life. Flexible means the teacher is given the flexibility to link the teaching materials from one subject to another, even with the student's life, and the state of the school and student environment. Learning outcomes in accordance with the interests and needs of students means that students are given the opportunity to optimize their potential in accordance with the interests and needs.

The principles of learning according to Fadlilah [1] which can be used as a reference by teacher in implementing learning, including the following: From the learners they are told to find out, b) From the teacher as the only source of learning to learn based on various sources of learning, c) From textual approach to the process as strengthening the use of scientific approach, d) From content-based learning to learning-based competence, e) From partial learning to integrated learning, f) From learning that emphasizes single answers to learning with answers that are multidimensional truths, g) From learning verbalism to applicative skills, h) Improvement and balance between the anthology of physical skills (hard skills) and mental skills (soft skills). i) Learning prioritizes the culture and culture of learners as lifelong learners, j) learning that implements the values by giving exemplars (ing ngarso sung tulodo), builds the will (ing madyo mangun karso) and develops the creativity of learners in the learning process (tut wuri handayani), k) Learning takes place at home, at school, and in society, l) Learning applies the principle of whoever is the teacher, who are the students, and where are the classes, m) The utilization of information and communication technologies to improve the efficiency and effectiveness of learning, n) recognition of individual differences and cultural background of learners.

By paying attention to these principles, it is expected that in the learning, teachers can develop various abilities of the learners in an interesting and fun way and can foster the spirit for learners to be more creative, independent, honest and responsible. The principles are applied in the learning activities in a unified or in integrated thematic learning thus the principles are interrelated with one and another.

\section{PlanNING OF INTEGRATED THEMATIC LEARNING}

The success of learning is largely determined by how far integrated learning is planned and packaged. Learning planning is designed in the form of syllabus and Learning Implementation Plan (RPP) which refers to the Content Standards. In the implementation of Curriculum 2013, themes are not negotiated with students, but already set by the government, even the thematic syllabus, teacher books, and student books have been provided by the government. For the purpose of applying integrated thematic learning in the classroom, teachers can develop thematic RPP by considering the thematic syllabus, teacher book, student book which have been available and referring to the applicable RPP format and sitemap.

\section{A. Principles of Lesson Plan (RPP) Preparation}

In the preparation and development of lesson plans to consider the principles of RPP development. According to Permendikbud No.65 Year 2013 [6], various principles in developing or preparing the RPP, namely as follows: a) individual differences of learners include initial ability, intellectual level, talent, potential, interest, learning motivation, social skills, emotions, learning styles, special needs, learning speed, cultural background, norms, values, and/or the environment of learners; b) active participation of learners; c) center on learners to encourage the spirit of learning, motivation, interest, creativity, initiative, inspiration, innovation and independence; d) the development of a culture of reading and writing designed to develop a passion for reading, reading comprehension, and expression in various forms of writing; e) Feedback and follow-up RPP includes the design of positive feedback, empowerment, enrichment, and remediation feedback programs; f) emphasis on the linkage and integration of KDs, learning materials, learning activities, indicators of competency achievement, assessment, and learning resources in a unified learning entity; g) accommodate thematic-integrated learning, cross-cutting integrity, crosslearning aspects, and cultural diversity; h) application of information and communication technology in an integrated, systematic, and effective according to the situation and conditions.

\section{B. Components of Lesson Plan (RPP)}

Before developing the RPP, it should be noted that the RPP component is in curriculum 2013. The RPP component in curriculum 2013 is regulated in Permendikbud no. 65 of 2013 [6], shall include the following: a) subject identity or theme/subtheme; b) class/semester; c) subject matter; d) allocation of time specified in accordance with the requirements for the achievement of $\mathrm{KD}$ and the burden of learning and taking into account the number of hours of lessons available in the syllabus and the KD to be achieved; e) learning objectives formulated based on $\mathrm{KD}$; f) basic competencies and indicators of achievement of competence; g) learning materials containing relevant facts, concepts, principles, and procedures; h) learning methods used by educators to realize the learning atmosphere and learning process so that learners achieve $\mathrm{KD}$ adjusted to the characteristics of learners and KD to be achieved; i) learning media, In the form of learning process aids to deliver the subject matter; j) learning resources, may be books, printed and electronic media, surrounding tools, and other relevant learning resources; k) learning steps through the preliminary, core, and closing stages; and l) assessment of learning outcomes. Based on the above description, Curriculum 2013 RPP component can be used as a reference in preparing a good and correct RPP. After paying attention to RPP component of Curriculum 2013. 


\section{The Process of Preparation of Thematic Lesson Plan}

The thematic RPP is an integrated thematic learning plan developed in detail from a theme. According to Permendikbud No. 81) in 2013 [1] Steps in preparing the lesson plan include: 1) reviewing the syllabus, 2) identifying learning materials, 3) determining learning objectives, 4) developing learning activities, 5) determine the allocation of time, 7) determine the source of learning. Explanation on the steps of preparing RPP Curriculum 2013 above as follows.

\section{1) Reviewing Syllabus}

In each syllabus, there are 4 Basic Competencies (KD) in accordance with the aspect of Core Competence (KI). Aspects of KI include attitudes to God, self-attitude and to the environment, knowledge, and skills. To achieve the 4 $\mathrm{KD}$, in the syllabus it is formulated the activities of learners in general in learning based on process standards.

\section{2) Identify Learning Materials}

In preparing the lesson plan teachers should identify the learning materials. According to Majid [4], learning material is "the material used to achieve the learning objectives". The learning material in the lesson plan is the development of the subject matter contained in the syllabus. Therefore, the learning materials in RPP should be developed in detail. According to Permendikbud No.81 A year 2013 on the implementation of curriculum [5] to identify learning materials, there are things that need to consider: a) Potential learners; b) relevance to regional characteristics; c) the level of physical development; d) the level of physical, intellectual, emotional, social, and spiritual development of learners; e) usefulness for learners; f) scientific structure; $g$ ) actuality, depth, and extent of learning materials; h) relevance to the needs of learners and environmental demands; i) time allocation.

\section{3) Determining Learning Objectives}

The purpose of learning related to the indicators of achievement of the competencies that have been set. Indicators of achievement of competencies are outlined from the basic competencies set out in the curriculum. According to Majid [4], the purpose of learning refers to the formula contained in the indicator in the form of an operational statement". In line with that, Fadlillah [1] states "The purpose of learning is everything to be achieved in the learning process and related to core competencies and basic competencies to be achieved."

Based on the above opinion the purpose of learning is everything to be achieved in the learning process that contains core competencies as well as basic competencies that refer to the indicators in the operational statement. In Sani's statement [6], learning objectives are formulated by considering audience, action or behaviour, conditions, and criteria, which can usually be abbreviated as A-B-C-D. Hearing (A) is the learner who becomes the subject of the learning objective. Actions or behaviours (B) are verbs that describe behaviour that can be measured or observed.

In formulating learning objectives, teachers should avoid unobservable verbs, such as: knowing, understanding, recognizing, learning, respecting, and so forth. Condition (C) is the limit of matter, place, situation to facilitate in evaluating. Criterion (D) is the standard that the learner (A) must attain so that it can be stated to have achieved the goal.

\section{4) Developing Learning Activities}

Achievement of Basic Competence (KD) should include activities in the learning of each meeting. This stage is a step in the implementation of teaching and learning process as an activity of learning adjusted to the components that have been prepared in previous planning. Learning activities include preliminary activities, core activities and closing activities. Preliminary activities are opening activities before entering the core activities to motivate student learning. The core activity is an important activity in learning because the core activities of learning, materials are delivered. While closing activities is a stabilization activity for mastery of teaching materials that can be a summary and follow-up direction on learning. Things to consider in developing the learning activities according to Permendikbud number 81A Year 2013 [1] i.e. a) Learning activities are structured to provide assistance for educators, especially teachers in order to implement the learning process professionally, b) learning activities contain a series of managerial activities undertaken by teachers so that learners can perform activities as stipulated in the syllabus. c) learning activities for each meeting is a scenario of teacher steps in making learners to actively learn. This activity is organized into activities: introduction, core, cover.

\section{5) Implementation of Assessment Type}

In the elucidation of the type of assessment, within the syllabus, it has been determined the type of assessment. Assessment of KD achievement of students is done based on indicators. Assessment is done using tests and non-test in both written and oral form, performance observation, attitude measurement, assessment of work in the form of tasks, projects and/or products, portfolio use, and selfassessment. The assessment component included in the RPP pursuant to Permendikbud Number 81A of 2013 [5].

\section{6) Determining Time Allocation}

In determining the time allocation in each KD it is based on the number of effective weeks and the effective allocation of time per week by considering the number of $\mathrm{KD}$, breadth, depth, difficulty level, and level of interest of KD. The time allocation included in the syllabus is the approximate average time to master the KD required by the varied learners. Therefore, the allocations are elaborated and adjusted again in the Lesson Plan.

\section{7) Determining Learning Resources}

Based on the preparation steps of the Lesson Plan described above, in Curriculum 2013 syllabus, teacher's books and student books have been provided by the government, so before developing RPP, a teacher should review the teacher's book and student's book. Explanation of the development of thematic RPP by reviewing teacher books and student books as follows.

\section{8) Reviewing Teachers' Books}

In the development of the thematic Lesson Plan in Curriculum 2013, a teacher needs to review the teacher's books provided by the government. Teacher's book is a blend 
for teachers to implement learning in the classroom. The teacher's book contains learning steps designed using a scientific approach in line with the demands of the 2013 curriculum. The teacher's book contains: (1) Graduate Competency Standards and Core Competencies (KI), (2) Basic Competence Mapping (KD) 1 and 2 and KD 3 and 4, (3) The scope of learning for a sub-theme consists of 6 lessons in a week (for class I), (4) Mapping of learning indicators for each lesson; (5) each lesson contains learning activities that include: the name of the activity, Learning objectives, media and learning tools, activity steps, assessment, (6) each time a lesson is ended, should the teacher perform a reflection activities to perform remedial activities and enrichment.

\section{9) Reviewing Students' Books}

In the development of Lesson Plan Curriculum 2013, what teachers should do is to examine the students' books. Students' book is a book intended for students used as a guide for learning activities to facilitate students in mastering certain competencies. Teachers are expected to be able to develop creative ideas further by utilizing the alternative activities offered in the teacher's book or developing their own learning ideas.

\section{IMPLEMENTATION OF INTEGRATED THEMATIC LEARNING}

Implementation of Integrated Thematic Learning is at the core of learning activities. In general, the implementation of learning consists of three main stages, namely: 1) preliminary / preliminary activities; 2) core activities; 3) closing activities. Based on Permendiknas Number 81A Year 2013 [2] described the three activities as follows.

\section{A. Preliminary Activities}

Preliminary activities are activities prior to entering the core of learning, usually the allocation of time for preliminary activities in 15 minutes. In the introductory activities, there are several activities that teachers can do to prepare students to receive the material.

According to Fadlillah[1], things that can be done by teachers include: a) Preparing students psychologically and physically to follow the learning, b) Start by reading the opening prayer lessons and greetings, c) Asking questions about the material that has been studied and related material to be studied, d) Deliver the learners to a problem or task that will be done to study a material and explain the learning objectives or KD to be achieved, e) Delivering the outline of the material coverage and explanation of the activities that will be done by the learners.

\section{B. Core Activity}

The core activities cannot be separated from the use of facilities and infrastructure, learning resources, media, methods and approaches undertaken by teachers. Teachers should be able to use facilities and infrastructure, learning resources and media and choose various methods and approaches for learning activities.

According to Majid [4], the implications of facilities, infrastructure, learning resources and media, among others: a) emphasizes students both individually and in groups to actively seek, explore and discover concepts and principles in a holistic and authentic way. Therefore, in its implementation it requires a variety of learning facilities and infrastructure, b) learning needs to take advantage of various sources of learning both in the design specific to the needs of the implementation of learning (by design), as well as learning resources available in the environment that can be utilized (by utilization), c) learning needs to optimize the use of various learning media that will help students in understanding abstract concepts, d) the application of thematic learning in Primary Schools can still use existing textbooks for each subject which is also possible to use a special supplement book containing integrated learning materials.

Based on the above statement, thematic learning requires the use of facilities, infrastructure, learning resources and media to support learning activities. In this case, teachers are required to be more creative in using facilities, infrastructure, learning resources and media for learning.

Learning methods should be adjusted to the characteristics of learners and subjects. In the implementation of learning, methods are necessary. Methods are used to achieve learning objectives. According to Sani [6], method is a way used to implement the plan that has been prepared in real activities for the objectives that have been prepared optimally achieved. Methods may vary depending on the teacher's material.

In this core activity, there is a process to instill attitudes, knowledge, and skills to learners. The process that can be done is by using scientific and thematic-integrative approach. Fadlillah [1] describes the thematic learning steps include: observing, questioning, associating, experimenting, and networking.

\section{Closing Activity}

The last activity in the learning activities is closing activities. The things that teachers and students can do during the final activities according to Fadlillah [1] are a) drawing conclusions on the whole set of learning activities and the results obtained to further jointly discover the direct or indirect benefits of the results, b) provide feedback on the learning process and outcomes, c) carry out follow-up activities in the form of assignments, both individual and group tasks, d) inform the lesson plan for the next meeting.

\section{Model, Method, InTEGRATED THEMATIC LEARNING MEDIA}

Discovery is a learning model developed based on the view of constructivism. This model emphasizes the importance of understanding structures or important ideas to a discipline, through the active involvement of students in the learning process.

Project-based learning is an innovative learning model and emphasise more on contextual learning through complex activities. Project-based learning is a learning model that provides an opportunity for educators or teachers to manage classroom learning by involving project work. 
competency assessment is undertaken through a performance appraisal, an assessment requiring learners to demonstrate a particular competency using practice tests, projects, and portfolio assessments. The instrument used is a checklist or a rating scale with a rubric.

\section{CONCLUSION}

Curriculum 2013 is a curriculum developed to enhance and balance the skills of soft skill and hard skill in the form of attitude, skills and knowledge. Curriculum 2013 emphasises the output of students who have character. The characters in question are 18 characters. Implementation of the implementation of learning includes initial activities, core activities, such as observing, questioning, reasoning, associating, experimenting, and networking and closing activity. Discovery is a learning model developed based on the view of constructivism. This model emphasizes the importance of understanding structures or important ideas to a discipline, through the active involvement of students in the learning process. Project-based learning is an innovative learning model and emphasises contextual learning through complex activities. Project-based learning is a learning model that provides an opportunity for educators or teachers to manage classroom learning by involving project work. Problem-based learning involves learners in an active, collaborative, learner-centred learning process that develops the problem-solving and self-learning skills needed to meet the challenges of life and careers, in today's increasingly complex environment. In choosing teacher learning media, teacher should be more selective and creative in developing the media. The media used is adapted to the material to be taught.

\section{REFERENCES}

[1] M. Fadlillah, Implementasi Kurikulum 2013 dalam Pembelajaran SD/MI, SMP/MTs, \& SMA/M, Yogyakarta: Ar-Ruzz Media, 2014, pp. 16,149, 153, 155-156, 174, 176-177, 182, 183, 184-185, 187.

[2] H.E. Mulyasa, Pengembangan dan Implementasi Kurikulum 2013, Bandung: PT. Remaja Rosdakarya, 2014.

[3] Rusman, Model-model Pembelajaran Mengembangkan Profesionalisme Guru, Bandung: Rajawali Press, 2010, p.251, 258259.

[4] A. Majid, Pembelajaran Tematik Terpadu, Bandung: PT. Remaja Rosdakarya, 2014, p.86, 126, 127, 190.

[5] Kemendikbud, Dasar Hukum Implementasi Kurikulum 2013 di Sekolah Dasar, Jakarta: Kementrian Pendidikan dan Kebudayaan, 2013, p.6, 154-155, 355.

[6] R. A. Sani, Pembelajaran Saintifik untuk Implementasi Kurikulum 2013, Jakarta: Bumi Aksara, 2014, p. 150, 261, 284, 287.

[7] Kunandar, Penilaian Autentik (Penilaian Hasil Belajar Peserta Didik Berdasarkan Kurikulum 2013) Suatu Pendekatan Praktis Disertai Contoh. Jakarta: Rajawali Pers, 2014, p. 104, 165, 257. 